\title{
SOME CHEMICAL, NUTRITIONAL AND MINERAL PROPERTIES OF DRIED JUNIPER (JUNIPERUS DRUPACEA L.) BERRIES GROWING IN TURKEY
}

\author{
ODABAŞ-SERIN, Z.* - BAKIR, O. \\ Kahramanmaraş Sütçü Imam University, Faculty of Forestry, Department of Forest Industry \\ Engineering, 46040 Kahramanmaraş, Turkey \\ *Corresponding author \\ e-mail: zehra@ksu.edu.tr; phone: +90-344-300-1780; fax: +90-344-300-1712 \\ (Received $18^{\text {th }}$ Feb 2019; accepted $8^{\text {th }}$ Apr 2019)
}

\begin{abstract}
Berries of Juniperus drupacea L. are important non-wood product used in traditional pekmez (fruit concentrate) production in Turkey. In this article, some chemical, nutritional and mineral properties of dried mature J. drupacea berries are reported. The materials were collected from Kahramanmaraş and Adana Provinces (Turkey). The results are given in the order of Kahramanmaraş and Adana; total dry matter 92.89 and $93.30 \%$, water soluble dry matter 62.40 and $57.07 \%$, protein 2.06 and $3.74 \%$, lipid 5.49 and $3.84 \mathrm{~g} / 100 \mathrm{~g}, \mathrm{pH} 5.53$ and 5.65, titretable acidity 0.38 and $0.52 \%, \mathrm{~K} 14.5$ and $17.3 \mathrm{~g} / \mathrm{kg}, \mathrm{Ca} 890.5$ and $794.7 \mathrm{mg} / \mathrm{kg}, \mathrm{Na} 67.0$ and $68.1 \mathrm{mg} / \mathrm{kg}, \mathrm{Mg} 439.2$ and $543.6 \mathrm{mg} / \mathrm{kg}, \mathrm{Fe} 33.8$ and $65.8 \mathrm{mg} / \mathrm{kg}, \mathrm{Cu} 4.4$ and $5.5 \mathrm{mg} / \mathrm{kg}$, Zn 16.5 and $18.1 \mathrm{mg} / \mathrm{kg}$ and finally $\mathrm{Mn} 4.7$ and $5.1 \mathrm{mg} / \mathrm{kg}$. In addition, holocellulose (carbohydrate) was determined as 14.29 and $16.01 \%$, lignin (phenolic compounds) as 16.94 and $18.98 \%$ and ash (inorganic constituents) content as 4.00 and 3.38\%. The soluble content of toluen/acetone/ethyl alcohol, hot water and cold water for Kahramanmaraş samples were 31.18, 67.08 and $60.74 \%$. They were 37.56, 63.36 and $55.81 \%$ for specimens from Adana. The berries from Kahramanmaraş showed higher lipid, soluble solid, $\mathrm{Ca}$ and ash contents than those from Adana.
\end{abstract}

Keywords: Syrian juniper, refractometer, protein, lipid, functional foods

\section{Introduction}

One of the juniper species in Turkey is $J$. drupacea which naturally grows in Mediterranean countries such as Turkey, Syria, Lebanon and Greece. Within this general distribution area, in the mountainous parts of the Eastern and Central Mediterranean regions of Turkey, it has a significant distribution between 600 and $1750 \mathrm{~m}$ altitude (Gültekin, 2014). It covers 958.423 ha which is $4.29 \%$ of the total forest area of country (OGM, 2015).

In Turkey, from the fruits of $J$. drupacea "pekmez" (fruit concentrate) is produced traditionally by the local people and used to treat asthma and bronchitis. It is an important foodstuff for people with high energy needs, mainly consumed in the winter months (Seca et al., 2015; Güneş et al., 2017).

Functional nutritional science has been very important nowadays. As average life expectation and healthcare costs rice, the people has investigated to become healthier and improve the quality of life. Functional foods may be "an essential macronutrient, or an essential micronutrient. While a macronutrient (e.g. carbohydrates, fats, and proteins) must be ingested in large amounts in human diet, a micronutrient (e.g. vitamins or minerals) must be consumed in certain trace amounts. Bioactive compounds are considered as the source of functional food effectiveness. Bioactive compounds can be categorized as "phenolic compounds, proteins, peptides and lipids, and carbohydrates (Martirosyan and Singh, 2015). 
Leaves, fruits, seeds and wood parts of junipers contain considerable chemical components. So, it takes important places in medicine, pharmacology and food industry. Juniper species are very miscellaneous and have been subject of researches by many scientists for it's oil, protein, reduced sugar, mineral, essential oil, phenolic compound content and antioxidant - antimicrobial activity properties (Nasri et al., 2011; Jalal et al., 2014; Hosseinihashemi, 2017; Salamon et al., 2017; Miceli et al., 2018).

Although there are many works about $J$. drupacea fruit concentrate (Özdemir et al., 2004; Ak1nc1 et al., 2004; Kocakulak, 2007; İzgi, 2011), less studies related to its dried fruit physical, chemical and mineral features are provided with. In the present study, some chemical (holocellulose, lignin, toluene-acetone-ethyl alcohol solubility, hot-cold water solubility and ash content), nutritional (total dry matter, water soluble dry matter, protein, lipid, $\mathrm{pH}$, titretable acidity) and mineral ( $\mathrm{K}, \mathrm{Ca}, \mathrm{Na}, \mathrm{Mg}, \mathrm{Fe}, \mathrm{Cu}, \mathrm{Zn}$ ve $\mathrm{Mn}$ ) components of dried mature fruit are identified.

\section{Materials and methods}

\section{Materials}

In this study, mature ripe juniper berries obtained from Kahramanmaraş-Andırın (KM) and Adana-Kozan (AA) in Eastern Mediterranean Region were used as experimental materials (Figure 1). The samples were collected in 2014, February-March and the information related to the places samples taken are given in Table 1 and Figure 2. Thirty berries were collected from each of the 30 randomly selected trees and a total of 900 berries were collected in each province. The collected samples were then dried in the laboratory environment under open air conditions. The dried samples were broken and seeds removed, later the remaining parts were grinded in the Willey-mill, sieved and preserved in glass jars.

\section{Methods}

The methods used to identify the main chemical components of the juniper berry: Holocellulose, lignin and ash content was determined according to Wise's chlorite method (Wise and Karl, 1962), TAPPI T222om-02 (2002) and TAPPI T211om-02 (2002) standards, respectively. Solubility properties, including toluene-acetone-ethyl alcohol $(4: 1: 1, \mathrm{w} / \mathrm{w})$ and cold - hot water solubilities were determined according to TAPPI T204cm-97 (1997) and TAPPI T207cm-99 (1999), respectively.

Methods for determining nutritional properties of $J$. drupacea berries are: Total dry matter was determined by drying the samples to a constant weight in a $65^{\circ} \mathrm{C}$ oven (AOAC, 1990). Soluble solid and $\mathrm{pH}$ values of the extract from the berries were determined by using a Hanna HI96801 refractometer and a $\mathrm{pH}$ meter (IFJU, 1968a, 1968b). Protein was calculated from the percentage of nitrogen found by using the Kjeldahl method (TS4895 EN ISO3188). Lipid content and titratable acidity of the samples were determined by the soxhlet extraction method, with hexane (AOAC, 1984) and by the titration method with, $0.1 \mathrm{~N} \mathrm{NaOH}$ (IFJU, 1968c), respectively. All chemical analysis results were calculated relative to oven dry sample weight.

To determine the mineral components of juniper berry the samples were burned with $\mathrm{HNO}_{3}(65 \%)$ and $\mathrm{H}_{2} \mathrm{O}_{2}(35 \%)$ solution in a microwave. Then, the absorbance of the extract was determined with the Atomic Absorbance Spectrophotometer, Perkin Elmer 
Optima 2100DV ICP-OES coupled with AS93 auto sampler. The mineral content was calculated with a standard curve.

To evaluate the significant differences between the mean values of each of the properties, independent-samples t-test analyses (ISTTA) were used. All statistical analyses were conducted by means of SPSS Statistics software, and the results were considered significant at $\mathrm{p} \leq 0.05$.
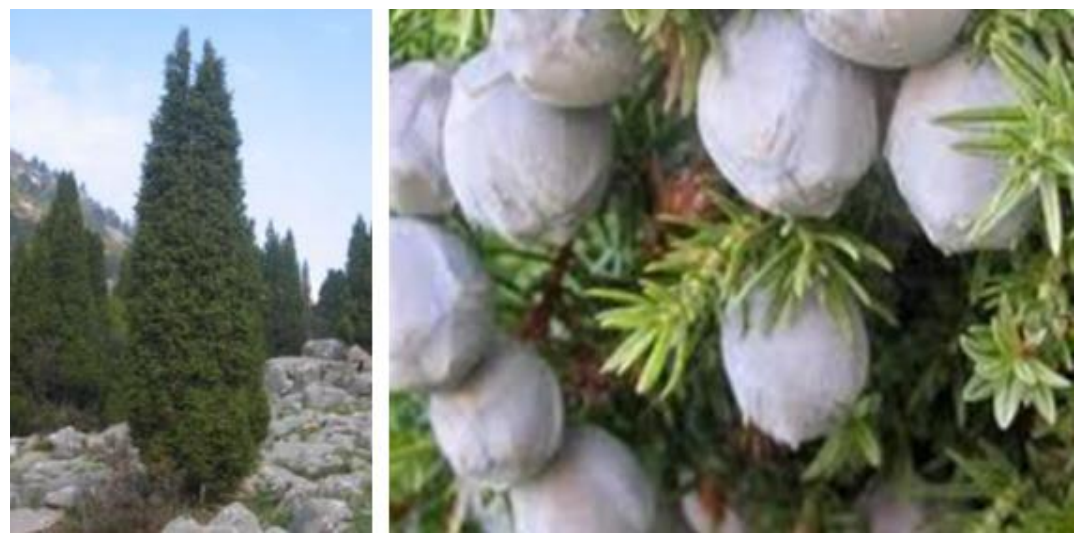

Figure 1. Juniperus drupacea tree, leaf and fruit (Kocakulak, 2007)

Table 1. Information for locations where juniper berries collected

\begin{tabular}{c|c|c|c}
\hline Location & Latitude & Longitude & Altitude (m) \\
\hline Kahramanmaraş-Andırın & $37^{\circ} 45^{\prime}$ & $36^{\circ} 42^{\prime}$ & 943 \\
Adana-Kozan & $37^{\circ} 38^{\prime}$ & $35^{\circ} 50^{\prime}$ & 895 \\
\hline
\end{tabular}

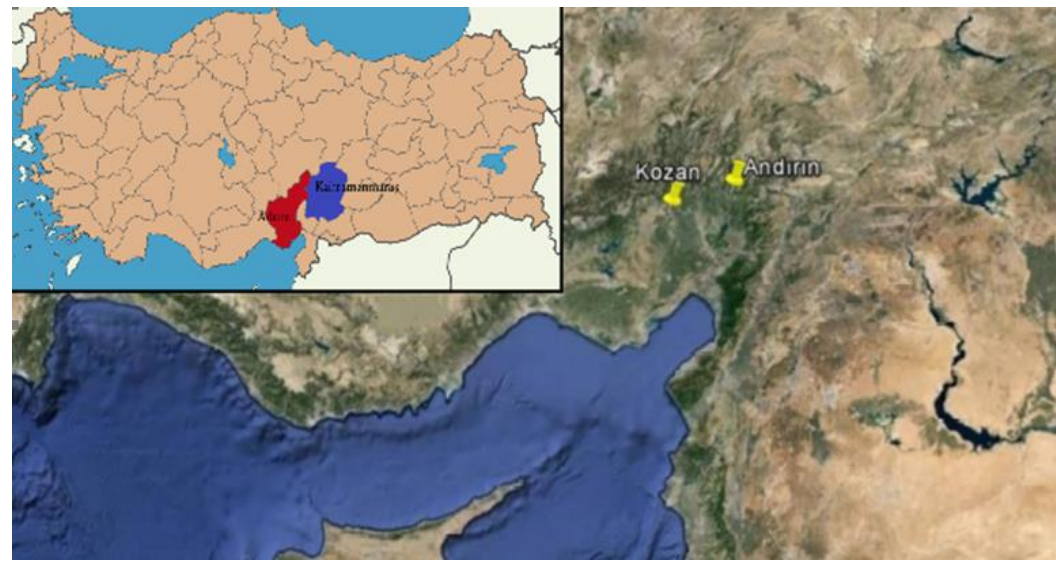

Figure 2. Geographical location of the study area in Turkey

\section{Results and discussion}

The main chemical, nutritional and mineral composition of $J$. drupacea dried berries are shown in Tables 1, 2 and 3, respectively. In order to compare the provided results, the properties of juniper berries from Akseki-Antalya (AY) from Western Mediterranean Region are also shown in Table 2 and Table 3. In addition to these, related properties of carob bean and raisins are given in the same tables, respectively. 
Table 2. Dried J. drupacea berries' main chemical components and their ratios

\begin{tabular}{c|ccc|cc}
\hline \multirow{2}{*}{ Component $(\%)$} & \multicolumn{3}{|c|}{ Determination } & \multicolumn{2}{c}{ Literature } \\
\cline { 2 - 6 } & KM berries & AA berries & Mean & $\begin{array}{c}\text { Softwoods } \\
(\text { Kirc1, 2006) }\end{array}$ & $\begin{array}{c}\text { Hardwoods } \\
\text { (Kirc1, 2006) }\end{array}$ \\
\hline Holocellulose & $14.29(0.38) \mathrm{b}$ & $16.01(0.31) \mathrm{a}$ & 15.15 & $63-70$ & $72-82$ \\
Lignin & $16.94(0.40) \mathrm{b}$ & $18.98(0.33) \mathrm{a}$ & 17.96 & $25-32$ & $18-26$ \\
Toluene/acetone/alcohol & $31.18(0.32) \mathrm{b}$ & $37.56(0.45) \mathrm{a}$ & 34.37 & $1-5.8$ & $1-6.2$ \\
solubility & $67.08(0.14) \mathrm{a}$ & $63.36(0.37) \mathrm{b}$ & 65.22 & $1-5$ & $1-8$ \\
Hot water solubility & $60.74(0.26) \mathrm{a}$ & $55.81(0.41) \mathrm{b}$ & 58.28 & $0.5-4$ & $0.2-4$ \\
Cold water solubility & $4.00(0.25) \mathrm{a}$ & $3.38(0.05) \mathrm{b}$ & 3.69 & $0.2-0.5$ & $0.2-0.7$ \\
Ash &
\end{tabular}

*KM= Kahramanmaraş, $\mathrm{AA}=$ Adana, $\mathrm{AY}=$ Antalya

$* *$ Values given in parentheses indicate $( \pm)$ standard deviations

$* * *$ Different letters in the same line represent statistical differences at the $95 \%$ confidence level

Table 3. Nutritional properties of J. drupacea dried berries

\begin{tabular}{c|ccc|cc}
\hline \multirow{2}{*}{ Content } & \multicolumn{3}{|c|}{ Determination } & \multicolumn{2}{c}{ Literature } \\
\cline { 2 - 5 } & $\begin{array}{c}\text { KM } \\
\text { berries }\end{array}$ & $\begin{array}{c}\text { AA } \\
\text { berries }\end{array}$ & Mean & $\begin{array}{c}\text { AY } \\
\text { Berries } \\
\text { (Ak1nc1 et al., 2004) }\end{array}$ & $\begin{array}{c}\text { Carob bean } \\
\text { (Kartier and } \\
\text { Art1k, 1995) }\end{array}$ \\
\hline Total dry matter (\%) & $92.89(0.11) \mathrm{b}$ & $93.30(0.00) \mathrm{a}$ & 93.10 & 76.57 & 91.60 \\
Soluble solid (\%) & $62.40(0.11) \mathrm{a}$ & $57.07(0.09) \mathrm{b}$ & 59.74 & 33.68 & 64.68 \\
Protein (\%) & $2.06(0.04) \mathrm{b}$ & $3.74(0.03) \mathrm{a}$ & 2.90 & 2.45 & 4.05 \\
Lipid (\%) & $5.49(0.09) \mathrm{a}$ & $3.84(0.03) \mathrm{b}$ & 4.67 & 4.28 & - \\
pH & $5.53(0.03) \mathrm{b}$ & $5.65(0.00) \mathrm{a}$ & 5.59 & 5.77 & 5.53 \\
Titretable acidity (\%,SSA) & $0.38(0.02) \mathrm{b}$ & $0.52(0.01) \mathrm{a}$ & 0.45 & - & 0.72 \\
\hline
\end{tabular}

*KM: Kahramanmaraş, AA: Adana, AY: Antalya

**Values given in parentheses indicate $( \pm)$ standard deviations

$* * *$ Different letters in the same line represent statistical differences at the $95 \%$ confidence level

\section{Chemical and nutritional properties of J. drupacea dried berries}

The major chemical components of natural lignocellulosic materials are holocellulose (total carbohydrate), lignin (phenolic compounds), ash (total inorganic constituents) and a very small fraction of so-called extractives (Fengel and Wegener, 1989; Chen, 2014). All these substances have an important place in human nutrition.

The average results and standard deviations of main chemical components of juniper berry from KM and AA are given in Table 2, the results of nutritional properties are given in Table 3. Juniper berry is a hard nut and cannot be consumed as a fresh fruit. So, general chemical properties of main components for softwoods and hardwoods are also given in Table 2.

As indicated in Table 2, the holocellulose mean ratio for juniper berry is $15.15 \%$ and this value is quite less than that in both softwood and hardwoods. With regard to lignin amount juniper samples (17.96\%), it showed hardwood characteristics. Phenolic substances have important contributions to human health. These compounds have been reported to play an effective role in preventing cancer and cardiovascular diseases by preventing free radical formation in the body (Gil et al., 2000). The results also showed that fruits from AA junipers have more lignin (18.98\%), in other words, more phenolic compounds than those from KM (16.94\%).

It is possible to remove waxes, oils, resins, photosterols, non-volatile hydrocarbons, low molecular weight carbohydrates, salts and other water soluble components present 
in the sample with neutral organic solvents (TAPPI T204cm-97, 1997). According to the results obtained, the solubility content of toluene/acetone/ ethyl alcohol (34.37\%) and the hot water $(65.22 \%)$ - cold water $(58.28 \%)$ of the samples were found to be fairly high when compared to softwood and hardwoods.

The ash content of juniper berry samples was determined as 3.69\%. This value found to be $2.51 \mathrm{~g} / 100 \mathrm{~g}$ for Antalya samples, $2.40 \%$ for raisins and $2.5 \%$ for carob bean (Karkacier and Artık, 1995; Akıncı et al., 2004; Kalkan et al., 2012). According to all these values, the amount of ash in KM and AA junipers berry found to be rather high.

When nutritional property mean values in Table 3 compared, soluble solid content was $62.40 \%$ for the berries from KM and $57.07 \%$ for AA samples. This value has been reported as $33.68 \%$ for AY juniper berry and $64.68 \%$ for carob bean (Karkacier and Artık, 1995; Akınc1 et al., 2004). The highness of this value is desirable. Accordingly, $\mathrm{KM}$ and AA soluble dry matter is $77.4 \%$ higher than AY specimen, and shows similarity to that from carob fruit.

Considering Table 3, the protein (3.74\%), $\mathrm{pH}(5.65)$ and titratable acidity $(0.52 \%)$ values of AA samples were higher than those for samples from KM as 2.06\%, 5.53 and $0.38 \%$, respectively. The lipid amount of KM samples was found to be $43 \%$ higher than that from AA. According to data from literature survey, the value for protein was found as: AY juniper berries $2.45 \%, J$. communis L. berries $4.28 \%$ and carob bean $4.05 \%$ (Karcıer and Artık, 1995; Akıncı et al., 2004; Bacém, 2018). According to results from the present work, titretable acidity value for juniper berries $(0.45 \% \mathrm{SSA})$ is more acidic than carob bean $(0.72 \%$ SSA).

\section{Mineral composition of J. drupacea dried berries}

Minerals have important place in human nutrition. The importance of these minerals, also known as trace elements, has been well understood in recent years, since when missed, causes diseases and major disorders in the human body (Bittencourt, 2018).

Mineral content and their ratio in KM and AA juniper berries are given in Table 4.

Table 4. Mineral composition of J. drupacea dried berries

\begin{tabular}{c|ccc|cc}
\hline \multirow{2}{*}{$\begin{array}{c}\text { Mineral } \\
\text { composition }\end{array}$} & \multicolumn{3}{|c|}{ Determination } & \multicolumn{2}{c}{ Literature } \\
\cline { 2 - 5 } & KM berries & AA berries & Mean & $\begin{array}{c}\text { AY berries } \\
\text { Akinc1 et al., } \\
\text { 2004) }\end{array}$ & $\begin{array}{c}\text { Raisins } \\
\text { (Kalkan et al., } \\
\text { 2012) }\end{array}$ \\
\hline $\mathrm{K}(\mathrm{g} / \mathrm{kg})$ & $14.5(\mathrm{~b})$ & $17.3(\mathrm{a})$ & $\mathbf{1 5 . 9}$ & 10.0 & 7.5 \\
$\mathrm{Ca}(\mathrm{mg} / \mathrm{kg})$ & $890.5(\mathrm{a})$ & $794.7(\mathrm{~b})$ & $\mathbf{8 4 2 . 6}$ & 1063.0 & 500.0 \\
$\mathrm{Na}(\mathrm{mg} / \mathrm{kg})$ & $67.0(\mathrm{~b})$ & $68.1(\mathrm{a})$ & $\mathbf{6 7 . 6}$ & 84.8 & 20.0 \\
$\mathrm{Mg}(\mathrm{mg} / \mathrm{kg})$ & $439.2(\mathrm{~b})$ & $543.6(\mathrm{a})$ & $\mathbf{4 9 1 . 4}$ & 477.0 & 70.0 \\
$\mathrm{Fe}(\mathrm{mg} / \mathrm{kg})$ & $33.8(\mathrm{~b})$ & $65.8(\mathrm{a})$ & $\mathbf{4 9 . 8}$ & 15.4 & 18.8 \\
$\mathrm{Cu}(\mathrm{mg} / \mathrm{kg})$ & $4.4(\mathrm{~b})$ & $5.5(\mathrm{a})$ & $\mathbf{4 . 9 5}$ & 29.2 & 3.2 \\
$\mathrm{Zn}(\mathrm{mg} / \mathrm{kg})$ & $16.5(\mathrm{~b})$ & $18.1(\mathrm{a})$ & $\mathbf{1 7 . 3}$ & 13.9 & 2.2 \\
$\mathrm{Mn}(\mathrm{mg} / \mathrm{kg})$ & $4.7(\mathrm{~b})$ & $5.1(\mathrm{a})$ & $\mathbf{4 . 9}$ & 9.0 & - \\
\hline
\end{tabular}

*KM: Kahramanmaraş, AA: Adana, AY: Antalya

$* *$ Letters in parentheses represent statistical differences at the $95 \%$ confidence level

Results showed that the amount of $\mathrm{K}(17.3 \mathrm{~g} / \mathrm{kg}), \mathrm{Na}(68.1 \mathrm{mg} / \mathrm{kg})$, $\mathrm{Mg}(543.6 \mathrm{mg} / \mathrm{kg}), \quad \mathrm{Fe} \quad(65.8 \mathrm{mg} / \mathrm{kg}), \quad \mathrm{Cu} \quad(5.5 \mathrm{mg} / \mathrm{kg}), \quad \mathrm{Zn} \quad(18.1 \mathrm{mg} / \mathrm{kg}) \quad$ ve Mn $(5.1 \mathrm{mg} / \mathrm{kg})$ from AA are higher than those in KM samples. In contrast, only the amount of $\mathrm{Ca}(890.5 \mathrm{mg} / \mathrm{kg})$ in $\mathrm{KM}$ berries is higher than that in AA $(794.7 \mathrm{mg} / \mathrm{kg})$. 
When the mean values of the results considered, KM and AA berries contain more $\mathrm{K}$, $\mathrm{Mg}, \mathrm{Fe}$ and $\mathrm{Zn}$ than $\mathrm{AY}$ berries and raisins. Inci et al. (2016) reported that Juniperus communis berries contained $61.2 \mathrm{~g} / \mathrm{kg} \mathrm{K}, 1.90 \mathrm{mg} / \mathrm{kg} \mathrm{Mg}, 80.12 \mathrm{mg} / \mathrm{kg} \mathrm{Fe}$, $15.31 \mathrm{mg} / \mathrm{kg} \mathrm{Mn}, 18.80 \mathrm{mg} / \mathrm{kg} \mathrm{Zn}$ and $19.94 \mathrm{mg} / \mathrm{kg} \mathrm{Cu}$. When we compared berries of $J$. drupacea and $J$. communis, it is seen that $J$. communis berries has a higher mineral content.

\section{Conclusion}

When the data obtained within the scope of the study considered, it can be mentioned that juniper berries collected from Kahramanmaras Province, found to be more oily, with more soluble solids, extractive matter (hot and cold water solubility), ash and calcium content than those from Adana Province samples. However, dried berries from Adana Province contains more holocellulose, lignin, protein and mineral matters $(\mathrm{K}$, $\mathrm{Na}, \mathrm{Mg}, \mathrm{Fe}, \mathrm{Cu}, \mathrm{Zn}, \mathrm{Mn}$ ).

When the data obtained within the scope of the study considered, it can be mentioned that juniper berry is a good source of minerals. It contains especially a fine ratio of Fe.

Acknowledgements. This study was supported by Kahramanmaraş Sütçü İmam University, BAP Department with project number 2015 / 2-33LAP.

\section{REFERENCES}

[1] Akıncı, İ., Özdemir, F., Topuz, A., Kabas, O., Çanakçı, M. (2004): Some physical and nutritional properties of Juniperus drupacea fruits. - J of Food Eng. 65: 325-331.

[2] AOAC (1984): Official Method. - 14th ed. Arlintong, VA, AOAC.

[3] AOAC (1990): Official Method. - 17th ed. Washington, DC, USA: Association of Official Analytical Chemists.

[4] Bacém, I. A. R. (2018): Composição química e atividade biológica de bagas do Zimbro (Juniperus communis L.). - Master Thesis, Instituto Politécnico de Bragança, 67p, Bragança.

[5] Bittencourt, J. A. (2018): The power of carbohydratesi proteins, and lipids. - Fourth Edition, CreateSpace.

[6] Chen, H. (2014): Biotechnology of lignocellulose theory and practice. - ISBN: 978-94007-6897-0, Springer, 510p.

[7] Fengel, G., Wegener, G. (1989): Wood chemistry, ultrastructure, reactions. - Walter de Gruyter. Berlin, New York, 611pp.

[8] Gil, M. I., Tomas-Barberan, F. A., Hess-Pierce, B., Holcroft, D. M., Kader, A. A. (2000): Antioxidant activity of pomegranate juice and its relationship with phenolic composition and processing. - J Agric Food Chem. 48: 4581-4589.

[9] Gültekin, H. C. (2014): Plant production techniques of important forest trees (conifers, leafy trees). - Republic of Turkey Ministry of Forestry and Water Management, Forest Management, Poplar and Rapidly Growing Forest Trees Research Institute. Publication Nr.271, İzmit, Turkey, 337pp.

[10] Güneş, S., Savran, A., Paksoy, A. Y., Koşar, M., Çakılcıŏglu, U. (2017): Ethnopharmacological survey of medicinal plants in Karaisalı and its surrounding (Adana-Turkey). - J of Herb Med. 8: 68-75. 
[11] Hosseinihashemi, S. K., Dadpour, A., Lashgari, A. (2017): Antioxidant activity and chemical composition of Juniperus excelsa ssp. polycarpos wood extracts. - Nat Prod Res. 31(6): 681-685.

[12] IFJU Analyses (1968a): Determination of soluble solids. - Nr.8. 21p.

[13] IFJU Analyses (1968b): Determination of measurement of $\mathrm{pH}$ value. - Nr.11, 2p.

[14] IFJU Analyses (1968c): Determination of titratable acid. - Nr.3, 4p.

[15] Inci, H., Ozdemir, G., Şengül, A. Y., Söğüt, B., Nursoy, H., Şengül, T. (2016): Using juniper berry (Juniperus communis) as a supplement in Japanese quail diets. - R Brasç Zootec. 45(5): 230-235.

[16] İzgi, N. (2011): Determination of composition of homemade andiz molasses, rheological characteristics, antioxidant and antimicrobial activities. - Namık Kemal University, Graduate School of Natural and Applied Sciences, Department of Food Engineering, MSc Thesis, Tekirdağ, Turkey.

[17] Jalal, F., Wassim, A., Issam, H. A. M. (2014): Chemical composition of essential oil extracted from syrian juniper berries (Juniperus drupacea L.). - Int. J of Agric Res. 9(3): $158-163$.

[18] Kalkan, N. N., Öz, M. H., Cang1, R. (2012): Determination of some physical-chemical properties and production techniques of Saruç. - J of Food and Feed Sci - Tech. 12: 1118.

[19] Karkacier, M., Artık, N. (1995): Determination of physical properties, chemical composition and extraction conditions of carob bean (Ceratonica siliqua L.). - The $\mathrm{J}$ of Food 20(3): 131-136.

[20] Kirc1, H. (2006): Pulp industry lecture notes. - Karadeniz Technical University, Forest Faculty Publication, Trabzon, Turkey.

[21] Kocakulak, E. (2007): Researches on the essential oils of Juniperus drupacea Lab. - Gazi University, Institute of Health Sciences, PhD Thesis, Ankara, Turkey.

[22] Martirosyan, D. M., Singh, J. (2015): A new definition of functional food by FFC: what makes a new definition unique? - Funct Foods in Health and Dis. 5(6): 209-223.

[23] Miceli, N., Marino, A., Köroğlu, A., Cacciola, F., Dugo, P., Mondello, L., Taviano, M. F. (2018): Comparative study of the phenolic profile, antioxidant and antimicrobial activities of leaf extracts of five Juniperus L. (Cupressaceae) taxa growing in Turkey. - Nat Prod Res. 1-6.

[24] Nasri, N., Tlili, N., Elfalleh, W., Cherif, E., Ferchichi, A., Khaldi, A., Triki, S. (2011): Chemical compounds from Phoenician juniper berries (Juniperus phoenicea). - Nat Prod Res. 25(18): 1733-1742.

[25] OGM (2015): The presence of Turkey's forests-2012. - Republic of Turkey General Directorate of Forestry, Ankara, Turkey, 31pp.

[26] Özdemir, F., Topuz, A., Gölükçü, M., Şahin, H. (2004): A study on improving process techniques of Juniperis drupacea's fruit pekmez. - The J of Food 29(1): 33-40.

[27] Salamon, I., Ibraliu, A., Kryvtsova, M., Petruska, P. (2017): Essential oil of common juniper (Juniperus communis L.) in Albania. - Sci. Bull. Uzhhorod Univ. (Ser. Biol.). 43: 72-75.

[28] Seca, A. M. L., Pinto, D. C. G. A., Silva, A. M. S. (2015): The Current Status of Bioactive Metabolites from the Genus Juniperus. - In: Bioactive Phytochemicals: Perspectives for Modern Medicine Vol.3, Daya Publishing House, 365-407.

[29] TAPPI T204cm-97 (1997): Solvent extractives of wood and pulp. - Tappi Press, Atlanta, GA.

[30] TAPPI T207cm-99 (1999): Water solubility of wood and pulp. - Tappi Press, Atlanta, GA.

[31] TAPPI T211om-02 (2002): Ash in wood, pulp, paper and paperboard: combustion at 525 oC. - Tappi Press, Atlanta, GA.

[32] TAPPI T222om-02 (2002): Acid-insoluble lignin in wood and pulp. - Tappi Press, Atlanta, GA. 
[33] TS 4895 EN ISO 3188 (1998): Starches and derived products - determination of nitrogen content by the Kjeldahl method-titrimetric method. - Turkish Standards Institution.

[34] Wise, E. L., Karl, H. L. (1962): Cellulose and hemicelluloses in pulp and paper science and technology. - In: Earl, C. L. (ed.) Vol. 1: Pulp. McGraw Hill-Book Co., New York. 